\title{
RESOURCES FROM RECYCLING AND URBAN MINING: LIMITS AND PROSPECTS
}

\author{
Franz-Georg Simon ${ }^{1, *}$ and Olaf Holm ${ }^{1,2}$ \\ ${ }^{1}$ Federal Institute for Materials Research and Testing, Unter den Eichen 87, Berlin 12205, Germany \\ 2 Thomé-Kozmiensky Verlag GmbH, Nietwerder, Dorfstraße 51, 16816 Neuruppin, Germany
}

Article Info:

Received:

5 March 2018

Revised:

11 June 2018

Accepted:

18 June 2018

Available online:

30 June 2018

Keywords:

Waste treatment

Secondary raw materials

Direct material input

Urban mining

\section{ABSTRACT}

Direct and indirect effects (DIERec) of the recovery of secondary resources are in the range of 500 million tons per year in Germany; energy savings are 1.4 million TJ. These savings are between 10 and $20 \%$ of the total. The effects of materials recovery exceed those of energy recovery by far except for secondary plastic material, where DIERec from energy recovery is higher by factor of 2.7. Untapped potential for the recovery of secondary resources exists in the fine fraction of bottom ash from municipal solid waste incineration, mainly $\mathrm{Cu}$ and precious metals, and in urban mining.

\section{INTRODUCTION}

Global resource consumption increased by a factor of 8 within the 20th century; the rise for metal ores was even by a factor of 18.8 (Krausmann et al., 2009). A reversal of this trend is not in sight. In Germany, direct material input (DMI, biotic, and abiotic resources) was 1,667 million tons in 2013 (Statistisches Bundesamt, 2017). Domestic extraction of raw materials (without unused extraction) was 1,060 million tons; roughly $20 \%$ of this mass accounted for by lignite for the generation of electricity. 607 million tons were imported. Extraction of gases (to balance with the output) was 1,084 million tons. On the output side are the exports (370 million tons), the dissipative losses (35 million tons), and the emissions to the atmosphere (845 million tons). The remaining 755 million tons are net addition to stock (713 million tons, e.g. in products, buildings, and infrastructure (Tanikawa \& Hashimoto, 2009)) and waste to landfills (42 million tons). Net addition to stock would be zero only in a perfect circular economy with constant population and constant affluence.

DMI does not account for resources used abroad in upstream chains expended for the production of the imported materials and goods. Converted to Raw Materials Equivalents, the figure for imports would be higher by a factor of roughly 3 (calculation for the year 2011: factor 2.74) (Buyny \& Lauber, 2009). DMI in raw material equivalents would be higher by $60 \%$.

The DMI would be even higher if only primary resources were used. Fortunately, the fraction of secondary raw materials in total resource consumption is considerable. The effect of the use of secondary raw materials can be estimated with the newly defined parameter DIERec (direct and indirect effects of recovery) (Steger et al., 2018). DIERec are the total savings of resources caused by using secondary raw materials, including all upstream chains on a global perspective. The direct effects of recovery (DERec) are, in contrast, limited to the domestic scale (Wagner et al., 2012). The DERec of a material flow is the additional amount that would be necessary to generate the substituted raw materials and energy in the absence of recycling and energy recovery, without considering upstream chains of processing and production abroad.

Calculation of DIERec is based on Cumulative Resource Demand (CRD), which considers all flows of raw material (including material flows associated with energy production, but without unused extraction, water, or air) back to the source. For metallic raw materials, the reciprocal metal content in an ore can be used as a proxy for CRD. For example, the copper content in today's ores is about $5 \times 10^{-3} \mathrm{~kg} / \mathrm{kg}_{\text {ore }}$. $\mathrm{CRD}_{\mathrm{Cu}}$ is therefore $200 \mathrm{~kg} / \mathrm{kg}$ (Simon \& Holm, 2017). CRD resembles the concept of Total Material Requirement (TMR), i.e., the total mass of primary material from nature. TMR includes both materials used for further processing and hidden flows that have not been further used, but have an environmental impact, such as overburden and extraction waste (Halada et al., 2001).

The use of secondary raw materials also saves energy. 
The amount can be calculated by comparing the Cumulative Energy Demand (CED, measured in terms of primary energy) of the process routes with and without secondary raw materials, $\triangle \mathrm{CED}$. The concept of CED is described in detail elsewhere (Verein Deutscher Ingenieure, 2012).

\section{EFFECTS OF RECOVERY IN GERMANY}

The direct and indirect effects of recovery (DIERec) were estimated for Germany in a recent study (Steger et al., 2018). Selected materials categories were 1.) metals, 2.) polymers, 3.) construction and mineral materials, and 4.) biomass- or fossil fuel-based materials. For this purpose, statistical data were retrieved from trade associations (e.g. Wirtschaftsvereinigung Metalle) and the German Federal Statistical Office (destatis) on primary and secondary resource use in Germany and abroad. Total material usage for these materials was 648 million tons in 2013; material flow from secondary production was 173 million tons (sums of column 1 and 2 in Table 1). The values for CRD were calculated by a method described in detail elsewhere (Saurat \& Ritthoff, 2013). The values for CRD in Table 1 are weighted mean net values for the respective material. For example, CRD for gold from primary production is 835,622 $\mathrm{kg} / \mathrm{kg}$. In secondary production, the value is 1,710 for the process of refinement and $0.06 \mathrm{~kg} / \mathrm{kg}$ in precious metals separating works.

For the category of polymers (i.e., PE, PS, PET, PVC and mixed plastics), DIERec was calculated to $3,366,000$ tons for materials recovery processes, i.e., substitution of primary plastic, wood, concrete, or heavy oil in the steel industry. Compared with other material flows, this figure is quite low; however, another 8,943,000 tons can be accounted for by DIERec from energy recovery using plastic waste. Here the assumption was made that $60 \%$ of the waste plastic was treated in municipal solid waste incineration plants and $40 \%$ in refuse-derived fuel plants. CRD for electricity (German electricity mix) is $0.175 \mathrm{~kg} / \mathrm{kg}$ and $0.18 \mathrm{~kg} / \mathrm{kg}$ for heat. The data for the individual plastic types differ substantially. For PET, the value for DIERec from material recovery was $1,440,000$ tons (more than $40 \%$ of the total) versus 348,000 tons from energy recovery, whereas the values DIERec for PP are 262,000 tons for material recovery and 2,254,000 tons energy recovery, respectively.

DIERec from materials recovery of food waste is negative because the substitution effects for nutrients $(1,096,000$ tons $)$ are outweighed by the expenses for collection and treatment (1,877,000 tons). In total, a positive value results together with the DIERec from energy recovery. As mentioned above, CRD in Table 1 are weighted net values. The low (net) value for wood $(0.7 \mathrm{~kg} / \mathrm{kg})$ is composed of CRD for substitution of primary wood $(2.77 \mathrm{~kg} / \mathrm{kg})$ and the respective expenses incurred by collection, transport etc.

The environmental impact of resource use can be related directly to the Cumulative Energy Demand (CED) (Huijbregts et al., 2010). In the study by Steger et al. (Steger et al., 2018), the energy savings $\triangle C E D$ resulting from the use of secondary resources was also calculated. The results are listed in Table 2. All values for $\triangle$ CED are related to materials and energy recovery. Energy savings from the materials recovery processes of plastic waste account for 110,346 TJ only and were even negative for food waste, at $-3,384 \mathrm{TJ}$.

Using secondary resources for Zn production requires more energy than in a complete primary production. This is visible in the negative $\triangle C E D$ value of $-6,924 \mathrm{TJ}$. The reason is the energy-consuming treatment of Zn-containing residues, e.g. in the Waeltz process or in hydrometallurgical processes. The case of recycling of $\mathrm{Zn}$ from flue gas cleaning residues was discussed in detail in the work of Fellner et al. (Fellner et al., 2015). It was shown that recovery of $\mathrm{Zn}$ is economic only under opportune circumstances such as extremely high Zn concentrations. However, any heavy metal recovery process at least avoids landfilling of otherwise problematic residues (Gehrmann et al., 2017).

The Direct and Indirect Effects of Recovery (DIERec) in Germany were in the range of 500 million tons in the year 2013 , more than $95 \%$ of this as a result of materials recovery, in contrast to energy recovery. This means that the raw material input of Germany (i.e., the DMI in terms of raw material equivalents (Buyny \& Lauber, 2009)) would be higher by approx. $18 \%$.

\section{WASTE MANAGEMENT OPTIONS}

The management of municipal solid waste (MSW) is an important part of the recovery of resources. In 2013, some 50 million tons of MSW were collected and delivered to different treatment processes. Landfilling of untreated waste stopped in Germany in 2005. Which treatment process is the best in view of resource recovery aspects and environmental compatibility is the subject of ongoing discussions. A variety of evaluation methods for waste treatment processes exist (Gehrmann et al., 2017). In a recent publication, four different waste management options - 1) disposal on landfills, 2) treatment in mechanical-biological treatment (MBT) plants, 3) treatment in municipal solid waste incineration (MSWI) plants, and 4) separate collection and individual treatment - were compared with regard to the potential of the reduction of greenhouse gas emissions (Wünsch \& Simon, 2018). The worst option regarding greenhouse gas emissions was option 1), with net emissions of 0.239 tons $\mathrm{CO}_{2 \text {, eq }}$ per ton of waste. Maximum reduction was achieved by option 4.), with -0.129 tons $\mathrm{CO}_{2^{\prime} \text { eq }}$ per ton of waste. This is in good agreement with the results from the DIERec study (Steger et al., 2018). Apart from the data for metals and large-volume waste streams such as recycled construction waste, DIERec for paper is among the highest values of all (27.1 million tons). This is possible through the separated collection of paper waste and subsequent treatment in the paper industry. Equally simple is materials recovery in the case of glass (DIERec 3.8 million tons, $\triangle$ CED 17,045 TJ). In contrast, separate collection of mixed plastic waste does not lead to a large effect in materials recovery; here energy recovery prevails. Options 2) (MBT) and 3) (MSWI) had reductions of -0.015 and -0.039 tons of $\mathrm{CO}_{2}$ eq per ton of waste, respectively.

A continuous source of secondary metals, which is exceptionally visible in the public eye, is MSWI bottom ash 
TABLE 1: Material flow from secondary production in Germany in 2013. Cumulative Resource Demand (CRD) can be used to calculate the Direct and Indirect Effects of Recovery (DIERec). All data are derived from (Steger et al., 2018).

\begin{tabular}{|c|c|c|c|c|c|}
\hline & $\begin{array}{l}\text { Total material } \\
\text { usage } \\
\text { (tons) }\end{array}$ & $\begin{array}{l}\text { Material flow from } \\
\text { second. production } \\
\text { (tons) }\end{array}$ & $\begin{array}{c}\text { CRD } \\
\text { (kg/kg) }\end{array}$ & $\begin{array}{c}\text { DIERec from material } \\
\text { recovery } \\
\left(10^{3} \text { tons }\right)\end{array}$ & $\begin{array}{l}\text { DIERec from energy } \\
\text { recovery } \\
\left(10^{3} \text { tons }\right)\end{array}$ \\
\hline \multicolumn{6}{|l|}{ Metals } \\
\hline Steel, iron & $42,645,000$ & $23,031,900$ & 6.1 & 139,545 & - \\
\hline Al & $2,980,000$ & 877,000 & 21 & 18,546 & - \\
\hline $\mathrm{Cu}$ & $1,389,000$ & 673,000 & 194 & 130,292 & - \\
\hline Stainless steel & $1,091,000$ & 412,000 & 55 & 22,723 & - \\
\hline $\mathrm{Zn}$ & 652,000 & 242,000 & 7.2 & 1,746 & - \\
\hline $\mathrm{Pb}$ & 367,000 & 134,000 & 29 & 3,872 & - \\
\hline Sn & 24,230 & 6,000 & 1,243 & 7,459 & - \\
\hline $\mathrm{Ag}$ & 4,135 & 479 & 8,985 & 4,304 & - \\
\hline Pt & 21 & 9.5 & 389,250 & 3,114 & - \\
\hline $\mathrm{Pd}$ & 21 & 8.0 & 47,263 & 449 & - \\
\hline $\mathrm{Au}$ & 40 & 7.6 & 835,000 & 6,346 & - \\
\hline Polymers & $19,800,000$ & $6,233,000$ & 2.0 & 3,366 & 8,943 \\
\hline \multicolumn{6}{|c|}{ Construction \& mineral materials } \\
\hline Recycl. constr. mat. & $497,000,000$ & $52,700,000$ & 1.0 & 55,066 & - \\
\hline Asphalt granulate & $41,000,000$ & $11,500,000$ & 1.1 & 12,137 & - \\
\hline Steel slags & & $10,540,000$ & 1.5 & 15,858 & - \\
\hline Power plant residues & & $8,547,000$ & 1.1 & 9,493 & - \\
\hline Glass cullet & $3,900,000$ & $2,470,000$ & 1.5 & 3,811 & - \\
\hline \multicolumn{6}{|c|}{ Biomass \& fossil fuel-based materials } \\
\hline Paper & $19,982,000$ & $16,489,000$ & 1.9 & 27,121 & 3,421 \\
\hline Food waste, compost & & $26,331,000$ & 0.02 & -782 & 1,413 \\
\hline Wood & $16,937,000$ & $11,230,000$ & 0.7 & 1,431 & 6,710 \\
\hline Textiles & & $1,083,000$ & 1.8 & 1,698 & 270 \\
\hline Tires & 550,000 & 442,000 & 2.2 & 722 & 232 \\
\hline
\end{tabular}

(BA). Around 5 million tons of MSWI BA were generated per year in Germany. The incineration itself serves as a concentrating and cleaning process for metals. However, due to the almost exclusive wet extraction out of the furnace chamber, the various metals are integrated in a heterogeneous and unstable matrix. The metal recovery is therefore still a challenge in terms of both recovery rate and purity (Holm \& Simon, 2017). With state-of-the-art treatment trains in Germany, around $7.7 \%$ of ferrous metals and $1.3 \%$ of nonferrous metals can be recovered from MSWI BA (Kuchta \& Enzner, 2015).

Today's focus in the recovery of nonferrous metals from municipal solid waste lies on Al and Cu alloys, which can be easily separated from a waste stream using eddy current separators. In 2013, 42,000 tons were recovered from MSWI BA, another 10,000 tons came from MBT. Together with aluminum scrap from other sources and post-consumer waste, 597,000 tons of secondary Al were produced in Germany in 2103 . However, the complete material flow of aluminum in Germany was almost 3 million $(2,980,000)$ tons. DIERec for the use of secondary $\mathrm{Al}$ is 18.5 million tons; $\triangle \mathrm{CED}$ is $166 \mathrm{PJ}$ (see tables). The reason for the high value of DIERec is the energy consumption of primary Al production, mainly of the fused-salt electrolysis step, which is not needed in Al scrap smelting. Material flows associated with energy production are included in DIERec. The conservation of natural resources is less relevant, because bauxite, the raw material for Al production, is a ubiquitous resource. This is different for copper. Production of secondary $\mathrm{Cu}$ is advantageous due to lower energy consumption and the conservation of ores, which have displayed a decreasing metal content over the last decades (Simon \& Holm, 2017).

Whereas the recovery rate for ferrous metals from MSWI BA is appropriate, the rate for nonferrous metals could be distinctively raised by carrying out innovative treatment trains and taking into account the fine fraction $<2 \mathrm{~mm}$. Particularly, the fraction of 1 to $2 \mathrm{~mm}$ contains an appreciable amount of nonferrous metals, so the recovery rate may be doubled in the future (Holm \& Simon, 2017). Whereas in coarser grain sizes, mainly $\mathrm{Al}, \mathrm{Cu}$, and brass occur, the fine fraction holds also precious metals (Holm et al., 2017; Morf et al., 2013; Muchova et al., 2009). Unpublished operation data (Gronholz, 2017) regarding refined heavy fractions of nonferrous metals (generated out of the grain size distribution 2 to $18 \mathrm{~mm}$ ) confirm the smelters' 
TABLE 2: Material flow from secondary production in Germany in 2013. Total $\triangle$ CED can be calculated from the specific Cumulative Energy Demand. All data are derived from (Steger et al., 2018).

\begin{tabular}{|c|c|c|c|}
\hline & $\begin{array}{l}\text { Material flow from second. } \\
\text { production } \\
\text { (tons) }\end{array}$ & $\begin{array}{l}\text { Specific CED } \\
(\mathrm{MJ} / \mathbf{k g})\end{array}$ & $\begin{array}{c}\text { Total energy savings ( } \triangle \mathrm{CED}) \\
(\mathrm{TJ})\end{array}$ \\
\hline \multicolumn{4}{|l|}{ Metals } \\
\hline Steel, iron & $23,031,900$ & 5.7 & 130,622 \\
\hline Al & 877,000 & 189 & 166,031 \\
\hline $\mathrm{Cu}$ & 673,000 & 53 & 35,935 \\
\hline Stainless steel & 412,000 & 56 & 23,243 \\
\hline $\mathrm{Zn}$ & 242,000 & -28.6 & $-6,924 *$ \\
\hline $\mathrm{Pb}$ & 134,000 & 13 & 1,759 \\
\hline Sn & 6,000 & 318 & 1,905 \\
\hline $\mathrm{Ag}$ & 479 & 8,232 & 3,943 \\
\hline $\mathrm{Pt}$ & 9.5 & 358,526 & 3,406 \\
\hline $\mathrm{Pd}$ & 8.0 & 82,000 & 656 \\
\hline $\mathrm{Au}$ & 7.6 & 238,026 & 1,809 \\
\hline Polymers & $6,233,000$ & 34.9 & 217,682 \\
\hline \multicolumn{4}{|c|}{ Construction \& mineral materials } \\
\hline Recycled constr. mat. & $52,700,000$ & 0.1 & 3,302 \\
\hline Asphalt granulate & $11,500,000$ & 1.5 & 17,045 \\
\hline Steel slags & $10,540,000$ & 2.3 & 24,129 \\
\hline Power plant residues & $8,547,000$ & 0.8 & 6,878 \\
\hline Glass cullet & $2,470,000$ & 9.0 & 22,293 \\
\hline \multicolumn{4}{|c|}{ Biomass- \& fossil fuel-based materials } \\
\hline Paper & $16,489,000$ & 32.1 & 529,671 \\
\hline Food waste, compost & $26,331,000$ & 0.5 & 14,344 \\
\hline Wood & $11,230,000$ & 12.5 & 140,563 \\
\hline Textiles & $1,083,000$ & 22.6 & 24,447 \\
\hline Tires & 442,000 & 40.9 & 18,082 \\
\hline
\end{tabular}

* A negative value indicates an increase in energy consumption instead a saving.

routine revenue for silver and gold (24 batches of 21.1 to 24.8 tons, i.e. more than 500 tons). Although the share of $\mathrm{Cu}$ in these batches averaged $64 \%$, the revenue for silver (2,672 ppm, variance 11\%) and gold (90 ppm, variance $31.4 \%$ ) together exceeded the revenue for $\mathrm{Cu}$ (Gronholz, 2017). Assuming realistic shares of around $70 \%$ for $\mathrm{Al}$ and $20 \%$ for $\mathrm{Cu}$ in the nonferrous metal fraction (optimistically $\sim 2.5 \%$ of the whole MSWI BA), the contribution of secondary production to the material flow in Germany would be 87,500 and 25,000 tons per year for $\mathrm{Al}$ and $\mathrm{Cu}$, respectively (Allegrini et al., 2014; Holm \& Simon, 2017).

\section{URBAN MINING}

The largest output fraction in the German material balance is the net addition to stock, i.e., 755 million tons in 2013. Most of this are construction materials, which are used partly for long-lasting buildings and infrastructure. Other components of the stock are vehicles and consumer goods. For Vienna, it was found that the copper stock (178 kg per capita) is distributed to $45 \%$ to buildings, $35 \%$ to infrastructure, $8 \%$ to vehicles, and the remaining $12 \%$ to consumer goods (Kral et al., 2014).
Thus, for copper, the building sector is the largest part of the urban mine.

For Vienna, a saturation was found for copper with an annual increase of $2 \%$ only, differing from Taipei with its increase of $26 \%$ per year to a today's much smaller copper stock of $28 \mathrm{~kg}$ per capita. Cities, in particular, therefore display a large reservoir for resources. In the future, this reservoir could be reused instead of geogenic ores; this is named urban mining. Baccini and Brunner define urban mining as the exploration and exploitation of material stocks in urban systems for anthropogenic activities (Baccini \& Brunner, 2012). They estimate the stock at 300-400 tons per capita (in cities). However, little is known about the exact quantity and quality. Also, separation and recovery methods in urban mining are still underdeveloped. Recovery of metals in urban mining is easier than recovery of minerals. In demolition projects, steel and copper can be separated in high purity, whereas the recovery of the mineral fraction is less straightforward and often ends up in downcycling. The same is true of the recovery of polymers from long-lasting products. End-of-life plastic is usually used as a fuel instead of a raw material or feedstock for 
polymer production, as shown in chapter 2 .

\section{CONCLUSIONS}

The direct and indirect effects of recovery in Germany are in the range of 500 million tons per year when resources used abroad in upstream supply chains are considered. Without the material flow from secondary production, the raw material input would be higher by almost $20 \%$. Energy savings from the use of secondary resources (1.4 million $\mathrm{TJ}$ in sum) are around $10 \%$ with regard to primary energy consumption in Germany. These figures are impressive; however, they show that a circular economy with no or only small additional input from primary resources is far off, even in mature industrialized economies like Germany with a fully developed recycling infrastructure. Resource consumption is still related to economic wealth. According to the well-known IPAT equation ( $=\mathrm{P} \times \mathrm{A} \times \mathrm{T}$ ), the environmental impact of resource consumption $(I)$ is the product of population $(P)$, affluence $(A)$, and a technology term $(T=1 /$ efficiency) (Ehrlich \& Holdren, 1971). As long as $P$ and $A$ increase, the only way to reduce environmental impact is technology that is more efficient. For the management of waste and an approach to urban mining, this is equivalent to an increase in separation efficiency. To close the loop, improved separation efficiency is needed in waste management and, more importantly due to its huge volume, in the construction sector (Maletz et al., 2018).

\section{REFERENCES}

Allegrini, E., Maresca, A., Olsson, M. E., Holtze, M. S., Boldrin, A., \& Astrup, T. F. (2014). Quantification of the resource recovery potential of municipal solid waste incineration bottom ashes. Waste Management, 34(9), 1627-1636. http://dx.doi.org/10.1016/j.wasman.2014.05.003.

Baccini, P., \& Brunner, P. H. (2012). Metabolism of the Anthroposphere, Analysis, Evaluation, Design. Cambridge, Massachusetts: MIT Press.

Buyny, S., \& Lauber, U. (2009). Weiterentwicklung des Indikators "Rohstoffproduktivität" der nationalen Nachhaltigkeitsstrategie, Berechnung der Importe und Exporte in Rohstoffäquivalenten. Wirtschaft und Statistik (11), 1133-1145.

Ehrlich, P. A., \& Holdren, J. P. (1971). Impacts of population growth. Science, $171,1212-1217$.

Fellner, J., Lederer, J., Purgar, A., Winterstetter, A., Rechberger, H., Winter, F., \& Laner, D. (2015). Evaluation of resource recovery from waste incineration residues - The case of zinc. Waste Management, 37, 95-103. http://dx.doi.org/10.1016/j.wasman.2014.10.010.

Gehrmann, H.-J., Hiebel, M., \& Simon, F.G. (2017). Methods for the Evaluation of Waste Treatment Processes. Journal of Engineering, 2017, 3567865 (3567861-3567813). https://doi. org/10.1155/2017/3567865.

Gronholz, C. (2017). [Tartech Eco Industries AG, Berlin; personal communication]

Halada, K., Ijima, K., Katagiri, N., \& Ohkura, T. (2001). An approximate estimation of total materials requirement of metals. Journal of the Japan Institute of Metals, 65(7), 564-570.
Holm, O., \& Simon, F. G. (2017). Innovative treatment trains of bottom ash (BA) from municipal solid waste incineration (MSWI) in Germany. Waste Management, 59, 229-236. http://dx.doi.org/10.1016/j. wasman.2016.09.004.

Holm, O., Wollik, E., \& Johanna Bley, T. (2017). Recovery of copper from small grain size fractions of municipal solid waste incineration bottom ash by means of density separation. International Journal of Sustainable Engineering, 1-11. https://doi.org/10.1080/193970 38.2017.1355415.

Huijbregts, M. A. J., Hellweg, S., Frischknecht, R., Hendriks, H. W. M., Hungerbühler, K., \& Hendriks, A. J. (2010). Cumulative Energy Demand As Predictor for the Environmental Burden of Commodity Production. Environmental Science \& Technology, 44(6), 21892196. https://doi.org/10.1021/es902870s.

Kral, U., Lin, C. Y., Kellner, K., Ma, H. W., \& Brunner, P. H. (2014). The Copper Balance of Cities, Exploratory Insights into a European and an Asian City. Jornal of Industrial Ecology, 18(3), 432-444.

Krausmann, F., Gingrich, S., Eisenmenger, N., Erb, K.-H., Haberl, H., \& Fischer-Kowalski, M. (2009). Growth in global materials use, GDP and population during the 20th century. Ecological Economics, 68(10), 2696-2705.

Kuchta, K., \& Enzner, V. (2015). Ressourceneffizienz der Metallrückgewinnung vor und nach der Verbrennung. In K. J. Thomé-Kozmiensky (Ed.), Mineralische Nebenprodukte und Abfälle 2 (pp. 105116). Neuruppin: TK Verlag.

Maletz, R., Dornack, C., \& Ziyang, L. (Eds.). (2018). Source Separation and Recycling, Implementation and Benefits for a Circular Economy (Handbook of Environmental Chemistry, Vol. 63): Springer International Publishing.

Morf, L. S., Gloor, R., Haag, O., Haupt, M., Skutan, S., Lorenzo, F. D., \& Böni, D. (2013). Precious metals and rare earth elements in municipal solid waste - Sources and fate in a Swiss incineration plant. Waste Management, 33(3), 634-644. http://dx.doi.org/10.1016/j. wasman.2012.09.010.

Muchova, L., Bakker, E., \& Rem, P. (2009). Precious metals in municipal solid waste incineration bottom ash. Water, Air and Soil Pollution: Focus, 9, 107-116.

Saurat, M., \& Ritthoff, M. (2013). Calculating MIPS 2.0. Resources, 2(4), 581-607. https://doi.org/10.3390/resources2040581.

Simon, F. G., \& Holm, O. (2017). Exergetische Bewertung von Rohstoffen am Beispiel von Kupfer. Chemie Ingenieur Technik, 89(1-2), 108-116. https://doi.org/10.1002/cite.201600089.

Statistisches Bundesamt. (2017). Umweltnutzung und Wirtschaft, Ausgabe 2016 (www.destatis.de), Wiesbaden.

Steger, S., Ritthoff, M., Dehoust, G., Bergmann, T., Schüler, D., Kosinka, I. Bulach, W., Krause, P., \& Oetjen-Dehne, R. (2018). Ressourcenschonung durch eine stoffstromorientierte Sekundärrohstoffwirtschaft (Saving Resources by a Material Category Oriented Recycling Product Industry) (FKZ 371493330 0). Umweltbundesamt (Federal Environmental Agency), Dessau (Germany).

Tanikawa, H., \& Hashimoto, S. (2009). Urban stock over time: spatial material stock analysis using 4d-GIS. Building Research \& Information, 37(5-6), 483-502. https://doi.org/10.1080/09613210903169394.

Verein Deutscher Ingenieure. (2012). Cumulative energy demand (CED) - Terms, definitions, method of calculation (VDI 4600). Beuth-Verlag, Berlin.

Wagner, J., Heidrich, K., Baumann, J., Kügler, T., \& Reichenbach, J. (2012). Determination of the contributions of the waste management sector to increasing resource productivity and of the share recycling takes in the value-added chain displaying the paths of recovery of relevant waste (UBA - FB 001608, Texte 14/2012). Umweltbundesamt, Dessau-Roßlau.

Wünsch, C., \& Simon, F. G. (2018). The Reduction of Greenhouse Gas Emissions Through the Source-Separated Collection of Household Waste in Germany. In R. Maletz, C. Dornack, \& Z. Lou (Eds.), Source Separation and Recycling - Implementation and Benefits for a Circular Economy. Berlin, Heidelberg: Springer International Publishing. https://doi.org/10.1007/698_2017_35. 